\title{
PENGARUH MOTIVASI DAN LINGKUNGAN KERJA TERHADAP KINERJA KARYAWAN PT. PUTRA TARO PALOMA BOGOR
}

\author{
Oleh: \\ Joni Heruwanto1), Dede Septian ${ }^{2)}$, Ergo Nurpatria Kurniawan ${ }^{3)}$ \\ joniheruwanto@yahoo.com ${ }^{1)}$,dedeseptian@yahoo.com ${ }^{2}$, ergo.mustgo@gmail.com ${ }^{3}$ \\ Sekolah Tinggi Ilmu Ekonomi IPWI Jakarta1,2,3)
}

\begin{abstract}
ABSTRAK
Penelitian ini dilakukan untuk mengetahui pengaruh motivasi kerja dan lingkungan kerja terhadap kinerja karyawan di PT. Putra Taro Paloma.

Populasi dan sampel diambil menggunakan rumus slovin dengan jumlah responden sebanyak 61 responden. Penelitian dilakukan dengan cara menyebarkan kuesioner kepada karyawan PT. Putra Taro Paloma, yang diteliti sebanyak 61 responden. Teknik analisis yang digunakan adalah regresi berganda dengan menggunakan uji hipotesis, yaitu uji F dan uji $t$.

Hasil data $R$ Square $\left(R^{2}\right)$ sebesar 0.457. Hal ini menunjukan bahwa sebesar 45,7\% variabel motivasi kerja dan variabel lingkungan kerja secara simultan berpengaruh terhadap kinerja, sedangkan sisanya 54,3\% dipengaruhi faktor lain yang tidak diteliti dalam penelitian ini. Motivasi kerja dan lingkungan kerja secara bersama-sama berpengaruh positif terhadap kinerja di PT. Putra Taro Paloma. $\hat{Y}=28.837+0.047 X 1+$ $0.108 X 2$. Hasil pengujian menunjukan bahwa secara parsial terdapat pengaruh signifikan motivasi kerja terhadap kinerja di PT. Putra Taro Paloma dan terdapat pengaruh lingkungan kerja terhadap kinerja di PT. Putra Taro Paloma.
\end{abstract}

Kata Kunci: Motivasi Kerja, Lingkungan Kerja, Kinerja

\section{PENDAHULUAN}

Dalam mencapai tujuan organisasi, karyawan memerlukan motivasi untuk bekerja lebih rajin. Dengan motivasi kerja yang tinggi, karyawan akan bekerja lebih giat dalam melaksanakan pekerjaannya dan sebaliknya. Selain faktor motivasi kerja, lingkungan kerja tempat karyawan tersebut bekerja juga tidak kalah pentingnya di dalam meningkatkan kinerja karyawan. Maka dari itu organisasi harus menyediakan lingkungan kerja yang memadai seperti lingkungan fisik (tata ruang kantor yang nyaman, lingkungan yang bersih, pertukaran udara yang baik, warna, penerangan yang cukup maupun musik yang merdu), serta lingkungan non fisik (suasana kerja karyawan, kesejahteraan karyawan, hubungan antar sesama karyawan, hubungan antar karyawan dengan pimpinan, serta tempat ibadah).
PT. Putra Taro Paloma adalah salah satu perusahaan yang bergerak dalam bidang industri makanan yang sering kita kenal dengan snack TARO. PT. Putra Taro Paloma, nampaknya masih terdapat banyak kendala yang dihadapi sehingga sulit untuk mencapai tujuan organisasi. Kondisi kendala di PT. Putra Taro Paloma antara lain karyawan datang kerja terlambat, pulang kerja lebih awal, ijin keluar masuk area produksi, ijin dikarenakan sakit, kurangnya sarana dan prasarana. Sehingga mengakibatkan kinerja karyawan menurun, sehingga pekerjaan karyawan tidak dapat terselesaikan sesuai dengan yang direncanakan.

Dalam kaitannya dengan kinerja karyawan, hal tersebut tentunya harus segera dibenahi agar para pimpinan dan bawahan dapat memberikan pelayanan yang prima kepada masyarakat secara lebih profesional. Penelitian ini 
dilakukan untuk mengetahui apakah motivasi dan lingkungan kerja mempunyai pengaruh signifikan terhadap kinerja karyawan dalam suatu organisasi pemerintah. Penelitian ini diharapkan dapat memberikan manfaat bagi organisasi dalam memberikan motivasi kepada karyawan sehingga tujuan organisasi dapat tercapai.

\section{TUJUAN PENELITIAN}

Untuk mengetahui apakah terdapat pengaruh motivasi dan lingkungan kerja terhadap kinerja karyawan pada PT. Putra Taro Paloma.

\section{TELAAH LITERATUR DAN PENGEMBANGAN PROPOSISI/HIPOTESIS Kinerja}

Pengertian kinerja adalah hasil kerja secara kualitas dan kuantitas yang dicapai oleh seorang pegawai dalam melaksanakan tugasnya sesuai dengan tanggung jawab yang diberikan padanya (Mangkunegara, 2013). Kinerja menurut Fahmi (2014) adalah hasil yang diperoleh oleh suatu organisasi baik organisasi tersebut bersifat profit oriented dan non profit oriented yang dihasilkan selama satu periode waktu. Menurut Simanjuntak dalam Widodo (2015) kinerja adalah tingkatan pencapaian hasil atas pelaksanaan tugas tertentu. Simanjuntak (2005) juga mengartikan kinerja individu sebagai tingkat pencapaian atau hasil kerja seseorang dari sasaran yang harus dilaksanakan dalam kurun waktu tertentu.

Kinerja karyawan adalah hasil dari proses pekerjaan tertentu secara berencana pada waktu dan tempat dari karyawan serta organisasi bersangkutan menurut Mangkuprawira dan Hubeis (2007:153). Menurut Wibowo (2010:7) mengemukakan bahwa "kinerja adalah tentang melakukan pekerjaan dan hasil yang dicapai dari pekerjaan tersebut."

Dari beberapa pendapat ahli dapat disimpulkan bahwa kinerja karyawan adalah hasil kerja yang dilakukan oleh seseorang dalam suatu organisasi agar tercapai tujuan yang diinginkan suatu organisasi dan meminimalisir kerugian. Dari beberapa pendapat ahli dapat disimpulkan bahwa kinerja karyawan adalah hasil kerja yang dilakukan oleh seseorang dalam suatu organisasi agar tercapai tujuan yang diiginkan suatu organisasi dan meminimalisir kerugian.

\section{Motivasi Kerja}

Dalam pengertian umum, motivasi dikatakan sebagai kebutuhan yang mendorong perbuatan ke arah suatu tujuan tertentu motivasi kerja adalah suatu yang menimbulkan semangat atau dorongan kerja. Motivasi adalah suatu proses dimana kebutuhankebutuhan mendorong seseorang untuk melakukan serangkaian kegiatan yang mengarah ke tercapainya tujuan tertentu. Tujuan yang jika berhasil dicapai akan memuaskan atau memenuhi kebutuhan-kebutuhan tersebut (Munandar, 2001).

Pamela dan Oloko (2015) motivasi adalah kunci dari organisasi yang sukses untuk menjaga kelangsungan pekerjaan dalam organisasi dengan cara dan bantuan yang kuat untuk bertahan hidup. Motivasi adalah memberikan bimbingan yang tepat atau arahan, sumber daya dan imbalan agar mereka terinspirasi dan tertarik untuk bekerja dengan cara yang anda inginkan (Chukwuma dan Obiefuna, 2014).

Steers dan Porter (dalam Miftahun dan Sugiyanto 2010) menyatakan bahwa motivasi kerja adalah suatu usaha yang dapat menimbulkan suatu perilaku, mengarahkan perilaku, dan memelihara atau mempertahankan perilaku yang sesuai dengan lingkungan kerja dalam organisasi. Motivasi kerja merupakan kebutuhan pokok manusia dan sebagai insentif yang diharapkan memenuhi kebutuhan pokok yang diinginkan, sehingga jika kebutuhan itu ada akan berakibat pada kesuksesan terhadap suatu kegiatan. Karyawan yang mempunyai motivasi kerja tinggi akan berusaha agar pekerjaannya dapat terselesaikan dengan sebaik-baiknya.

Motivasi adalah salah satu faktor paling penting yang mempengaruhi perilaku manusia dan kinerja. Teori 
motivasi telah dibahas dan dikonsep oleh berbagai peneliti. Tingkat motivasi seorang individu atau tim diberikan dalam tugas atau pekerjaan mereka yang dapat mempengaruhi semua aspek kinerja organisasi. Dalam penelitian terbaru, motivasi didefinisikan sebagai kesediaan untuk mengerahkan tingkat tinggi usaha, menuju tujuan organisasi, yang dikondisikan oleh kemampuan upaya untuk memenuhi beberapa kebutuhan individual.

Berdasarkan beberapa pendapat yang dikemukakan oleh para ahli dapat disimpulkan bahwa motivasi kerja adalah suatu proses dimana kebutuhan mendorong seseorang untuk melakukan serangkaian kegiatan yang mengarah ke tercapainya tujuan tertentu dan tujuan organisasi dan untuk memenuhi beberapa kebutuhan. Kuat lemahnya motivasi kerja seorang tenaga kerja ikut menentukan besar kecilnya prestasi.

\section{Lingkungan Kerja}

Lingkungan kerja dalam suatu perusahaan perlu diperhatikan, hal ini disebabkan karena lingkungan kerja mempunyai pengaruh langsung terhadap para karyawan. Lingkungan kerja yang kondusif dapat meningkatkan kinerja karyawan dan sebaliknya, lingkungan kerja yang tidak memadai akan dapat menurunkan kinerja karyawan. Kondisi lingkungan kerja dikatakan baik apabila manusia dapat melaksanakan kegiatan secara optimal, sehat, aman, dan nyaman. Kesesuaian lingkungan kerja dapat dilihat akibatnya dalam jangka waktu yang lama. Lingkungan kerja yang kurang baik dapat menuntut tenaga kerja dan waktu yang lebih banyak dan tidak mendukung diperolehnya rancangan sistem kerja yang efisien.

Menurut Basuki dan Susilowati (2005:40) lingkungan kerja adalah segala sesuatu yang berada di lingkungan yang dapat mempengaruhi baik secara langsung maupun tidak langsung seseorang atau sekelompok orang di dalam melaksanakan aktivitasnya. Menurut Robbins \& Coulter (2012) lingkungan adalah lembaga-lembaga atau kekuatan- kekuatan di luar yang berpotensi memengaruhi kinerja organisasi. Lingkungan dirumuskan menjadi dua yaitu lingkungan umum dan lingkungan khusus. Lingkungan umum adalah segala sesuatu di luar organisasi yang memilki potensi untuk memengaruhi organisasi. Lingkungan ini berupa kondisi sosial dan teknologi. Sedangkan, lingkungan khusus adalah bagian lingkungan yang secara langsung berkaitan dengan pencapaian sasaransasaran sebuah organisasi.

Masalah lingkungan kerja dalam suatu organisasi sangatlah penting, dalam hal ini diperlukan adanya pengaturan maupun penataan faktorfaktor lingkungan kerja dalam penyelenggaraan aktivitas organisasi. Sesuai dengan Keputusan Menteri Kesehatan No. 261/MENKES/SK/II/ 1998 Tentang Persyaratan Kesehatan Lingkungan Kerja bahwa lingkungan kerja perkantoran meliputi semua ruangan, halaman dan area sekelilingnya yang merupakan bagian atau yang berhubungan dengan tempat kerja untuk kegiatan perkantoran. Persyaratan kesehatan lingkungan kerja dalam keputusan ini diberlakukan baik terhadap kantor yang berdiri sendiri maupun yang berkelompok.

Dari pendapat para ahli dapat disimpulkan bahwa lingkungan kerja adalah segala sesuatu yang ada di sekitar karyawan pada saat bekerja baik berupa fisik maupun nonfisik yang dapat mempengaruhi karyawan saat bekerja. Jika lingkungan kerja yang kondusif maka karyawan bisa aman, nyaman dan jika lingkungan kerja tidak mendukung maka karyawan tidak bisa aman dan nyaman.

\section{Hipotesis}

Hipotesis untuk menjelaskan pengaruh motivasi kerja dan lingkungan kerja terhadap kinerja pada PT. Putra Taro Paloma yang diajukan pada penelitian ini adalah:

$H 1$ : Terdapat pengaruh motivasi terhadap kinerja karyawan pada PT. Putra Taro Paloma. 
H2 : Terdapat pengaruh lingkungan terhadap terhadap kinerja karyawan pada PT. Putra Taro Paloma.

\section{METODE PENELITIAN Sampel Penelitian}

Populasi adalah wilayah generalisasi yang terdiri atas obyek/subyek yang mempunyai kualitas dan karakteristik tertentu yang ditetapkan oleh peneliti untuk dipelajari kemudian ditarik kesimpulannya (Sugiyono, 2014:80). Penulis mengambil populasi yang digunakan dalam penelitian ini adalah seluruh karyawan PT. Putra Taro Paloma yang berjumlah 155 orang.

Menurut Sugiyono (2014:81) sampel adalah sebagian dari jumlah dan karakteristik yang dimiliki oleh populasi tersebut. Agar sampel yang diperoleh representative, peneliti menggunakan rumus slovin (Umar, 2005:120), yaitu sebagai berikut:

Keterangan:

$$
n=\frac{N}{1+N(e)^{2}}
$$

$\mathrm{n}=$ jumlah sampel

$\mathrm{N}=$ jumlah populasi

$\mathrm{e}=$ prosentase kelonggaran karena kesalahan pengambilan sampel yang masih ditolelir (ketidaktelitian).

Dalam penelitian ini, $\mathrm{N}=155$ dan e $=10 \%$ maka:

$n=\frac{155}{1+155(10 \%)^{2}}$

$n=\frac{155}{1+155(0.1)^{2}}$

$n=\frac{155}{1+1.55}$

$n=60.784 \longrightarrow 61$

Berdasarkan perhitungan di atas didapatkan jumlah sampel sebesar 61 dari 155 jumlah karyawan di PT. Putra Taro Paloma.

\section{Operasionalisasi Variabel}

Variabel penelitian adalah segala sesuatu yang berbentuk apa saja yang ditetapkan oleh peneliti untuk dipelajari sehingga diperoleh informasi tentang hal tersebut. Agar penelitian ini dapat dilaksanakan sesuai dengan yang diharapkan, maka perlu dipahami berbagai unsur-unsur yang menjadi dasar dari suatu penelitian ilmiah yang termuat dalam operasionalisasi variabel penelitian. Secara lebih rinci, operasionalisasi variable penelitian adalah sebagai berikut:

Tabel 1

Operasionalisasi Variabel

\begin{tabular}{|c|c|c|c|}
\hline Variabel & Indikator & Skala & $\begin{array}{c}\text { Item } \\
\text { Pernyataan }\end{array}$ \\
\hline $\begin{array}{l}\quad \text { Kinerja }(\mathrm{Y}) \\
\text { Menurut Wibowo }(2010: 7) \\
\text { mengemukakan bahwa: } \\
\text { "kinerja adalah tentang } \\
\text { melakukan pekerjaan dan hasil } \\
\text { yang dicapai dari pekerjaan } \\
\text { tersebut." }\end{array}$ & $\begin{array}{l}\text { - Kuantitas } \\
\text { - Kualitas } \\
\text { - Keandalan } \\
\text { - Kehadiran } \\
\text { - Kemampuan } \\
\text { bekerja sama }\end{array}$ & 1.5 & $\begin{array}{l}1,2 \\
3,4 \\
5,6 \\
7,8 \\
9,10\end{array}$ \\
\hline $\begin{array}{l}\quad \text { Motivasi Kerja (X1) } \\
\text { Pamela \& Oloko (2015) motivasi } \\
\text { adalah kunci dari organisasi } \\
\text { yang sukses untuk menjaga } \\
\text { kelangsungan pekerjaan dalam } \\
\text { organisasi dengan cara dan } \\
\text { bantuan yang kuat untuk } \\
\text { bertahan hidup kepuasan. }\end{array}$ & \begin{tabular}{|l} 
- Kebutuhan \\
fisiologis \\
- Kebutuhan rasa \\
aman \\
- Kebutuhan sosial \\
- Kebutuhan \\
penghargaan \\
- Kebutuhan \\
aktualisasi diri
\end{tabular} & 1.5 & $\begin{array}{l}11,12 \\
13,14 \\
15,16 \\
17,18,19 \\
20,21\end{array}$ \\
\hline $\begin{array}{l}\quad \text { Lingkungan Kerja (X2) } \\
\text { Sedarmayanti (2009:28) } \\
\text { lingkungan adalah lembaga- } \\
\text { lembaga atau kekuatan- } \\
\text { kekuatan diluar yang } \\
\text { berpotensi memengaruhi } \\
\text { kinerja organisasi. }\end{array}$ & $\begin{array}{l}\text { - Suasana kerja } \\
\text { - Hubungan } \\
\text { dengan rekan } \\
\text { kerja } \\
\text { - Tersedianya } \\
\text { fasilitas kerja } \\
\text { - Penerangan } \\
\text { / cahaya } \\
\text { - Sirkulasi udara } \\
\text { - Kebisingan } \\
\text { - Bau tidak sedap } \\
\text { - Keamanan }\end{array}$ & 1.5 & $\begin{array}{l}22,23 \\
24,25 \\
26,27 \\
28,29 \\
30,31 \\
32,33 \\
34,35 \\
36,37\end{array}$ \\
\hline
\end{tabular}

\section{Metode Sampling}

Sampling adalah suatu cara pengumpulan data yang sifatnya tidak menyeluruh, yaitu tidak mencakup seluruh objek penelitian (populasi) akan tetapi sebagian saja dari populasi. Sugiyono (2014:116) menyatakan bahwa "teknik sampling adalah merupakan teknik pengambilan sampel."

Untuk penentuan sampel dalam penelitian ini menggunakan teknik proportional area random sampling yaitu teknik pengambilan sampel yang diambil dari masing-masing subpopulasi yang diambil secara acak berdasarkan proporsi jumlah karyawan yang ada 
pada tiap subpopulasi sejumlah sampel 61 orang.

\section{Metode Pengumpulan Data}

Metode pengumpulan data merupakan metode atau cara yang digunakan peneliti untuk mendapatkan data dalam suatu penelitian. Dalam penelitian ini metode yang digunakan untuk mengumpulkan data adalah:

\section{Observasi}

Teknik observasi yaitu teknik pengumpulan data yang dilakukan dengan pengamatan langsung terhadap aktivitas karyawan di PT. Putra Taro Paloma.

\section{Angket (kuesioner)}

Teknik angket adalah suatu cara pengumpulan data dengan menyebarkan pertanyaan kepada responden dan responden akan memberikan respon atas pertanyaan tersebut (Umar, 2005:82). Pemilihan teknik angket dalam penelitian ini agar memperoleh data yang akurat secara langsung dari orang-orang yang akan dimintai data. Dalam penelitian ini, skala pengukuran yang digunakan adalah skala Likert, yaitu skala yang digunakan untuk mengukur pendapat orang atau sekelompok orang tentang fenomena sosial.

\section{Dokumentasi}

Teknik dokumentasi adalah pengumpulan data dan informasi melalui arsip dan dokumentasi (Umar, 2005:83). Untuk memperoleh data pendukung yang dibutuhkan dari sumber yang dapat dipercaya, maka digunakan teknik dokumentasi. Teknik dokumentasi berguna untuk memperoleh data tentang jumlah karyawan dan data tentang gambaran umum PT. Putra Taro Paloma, dan datadata lain yang mendukung.

\section{Metode Analisis}

\section{Validitas}

Uji validitas dilakukan dengan membandingkan nilai $r$ hitung (kolom Corrected Item-Total Correlation) dengan $r$ tabel (harus lihat tabel $r$ ) dimana butir pernyataan valid apabila memiliki $r$ hitung > $\mathrm{r}$ tabel. Untuk mempermudah maka beberapa ahli menyatakan bahwa pernyataan valid apabila nilai Korelasi (kolom Corrected Item-Total Correlation) $>0,3$.

Uji validitas menyatakan bahwa instrumen yang digunakan untuk mendapatkan data dalam penelitian dapat digunakan atau tidak. Menurut Sugiyono (2014:121) menyatakan bahwa valid berarti instrumen tersebut dapat digunakan untuk mengukur apa yang seharusnya diukur.

Untuk mencari nilai validitas di sebuah item mengkorelasikan skor item dengan total item-item tersebut. Jika ada item yang tidak memenuhi syarat, maka item tersebut tidak akan diteliti lebih lanjut. Syarat tersebut menurut Sugiyono (2014:133) yang harus dipenuhi yaitu harus memiliki kriteria sebagai berikut:

a. Jika $r$ hitung $>r$ tabel, maka itemitem tersebut dinyatakan valid.

b. Jika $r$ hitung < $r$ tabel, maka itemitem tersebut dinyatakan tidak valid.

\section{Reliabilitas}

Reliabilitas adalah indeks yang menunjukkan sejauhmana suatualat pengukur (daftar pernyataan) dapat dipercaya atau dapatdiandalkan. Uji reliabilitas dilakukan terhadap keseluruhan butir pernyataan yang telah valid. Uji reliabilitas dilakukan dengan metode Cronbach's Alpha. Reliabilitas terpenuhi jika nilai Cronbach's Alpha > 0,6 (Nunnally dalam Mulyanto dan Wulandari, 2012:126).

\section{Uji Normalitas}

Normalitas harus terpenuhi yang menunjukkan bahwa data variabel penelitian berasal dari data variabel yang berdistribusi normal. Normalitas data pada analisis regresi linier ganda dalam penelitian ini dilakukan secara grafik yaitu menggunakan Normal P-P Plot. Normalitas terpenuhi jika titik-titik pada grafik Normal P-P Plot menyebar di sekitar dan mengikuti garis diagonal grafik.

\section{Uji Autokorelasi}

Model regresi yang baik adalah yang tidak terjadi autokorelasi dimana pengujian dilakukan dengan melihat 
nilai Durbin-Watson hasil pengolahan data dibandingkan dengan nilai dl dan du pada Durbin-Watson tabel dengan kriteria sebagai berikut:

- $1.21<\mathrm{DW}<1.65$ = tidak dapat disimpulkan

- $2.35<\mathrm{DW}<2.79=$ tidak dapat disimpulkan

- $1.65<\mathrm{DW}<2.35=$ tidak terjadi autokorelasi

- DW $<1.21$ dan DW $>2.79=$ terjadi autokorelasi

\section{Uji Multikolineritas}

Uji multikolinieritas bertujuan untuk menguji apakah pada sebuah model regresi ditemukan adanya korelasi antar variabel independen. Jika terjadi korelasi, maka dinamakan terdapat problem multikolinieritas. Model regresi yang baik seharusnya tidak terjadi korelasi di antara variabel independen. Jika terbukti ada multikolinieritas, sebaiknya salah satu dari variabel independen yang ada dikeluarkan dari model, lalu pembuatan model regresi diulang kembali (Santoso, 2012:234).

Untuk mendeteksi ada tidaknya multikolinieritas dapat dilihat pada besaran Variance Inflation Factor (VIF) dan Tolerance. Pedoman suatu model regresi yang bebas multikolinieritas adalah mempunyai angka tolerance mendekati 1. Batas VIF adalah 10, jika nilai VIF di bawah 10, maka tidak terjadi gejala multikolinieritas (Gujarati, 2012:432).

\section{Pengujian Hipotesis}

Sebelum dilakukan pengujian hipotesis, terlebih dahulu dilakukan uji kelayakan model yaitu menganalisis kemampuan model persamaan regresi linier ganda dalam menjelaskan pengaruh motivasi kerja dan lingkungan kerja terhadap kinerja pada PT. Putra Taro Paloma. Hipotesis statistik yang diajukan adalah sebagai berikut:

Ho $: \rho=0:$ tidak layak

Ha $: \rho \neq 0:$ ada layak

Pengujian hipotesis dilakukan dengan uji-F yaitu membandingkan nilai probabilitas (sig F) terhadap taraf uji penelitian ( $\mathrm{a}=0.05)$. Kriteria yang digunakan untuk menguji hipotesis penelitian adalah sebagai berikut:

- Jika sig $\mathrm{F}<\mathrm{a}$, maka Ho ditolak dan Ha diterima, artinya model hasil penelitian layak digunakan untuk menjelaskan pengaruh motivasi kerja dan lingkungan kerja terhadap kinerja pada PT. Putra Taro Paloma

- Jika sig F > a, maka Ho diterima dan Ha ditolak, artinya model hasil penelitian tidak layak digunakan untuk menjelaskan pengaruh motivasi kerja dan lingkungan kerja terhadap kinerja pada PT. Putra Taro Paloma

Pengujian hipotesis penelitian dilakukan dengan uji-t. Pengujian hipotesis dalam penelitian sebanyak dua kali sesuai dengan hipotesis penelitian.

\section{Uji hipotesis pertama}

Hipotesis pertama yang diajukan dalam penelitian ini adalah terdapat pengaruh motivasi kerja terhadap kinerja pada PT. Putra Taro Paloma. Hipotesis statistik yang diajukan adalah sebagai berikut:

- H1o: b1 = 0 : tidak ada pengaruh

- H1a: $\mathrm{b} 1 \neq 0$ : ada pengaruh

Pengujian hipotesis dilakukan dengan uji-t yaitu membandingkan nilai probabilitas (sig t) terhadap taraf uji penelitian ( $\mathrm{a}=0.05)$. Kriteria yang digunakan untuk menguji hipotesis penelitian adalah sebagai berikut:

- Jika sig $\mathrm{t}<\mathrm{a}$, maka H1o ditolak dan $\mathrm{H} 1 \mathrm{a}$ diterima, artinya terdapat pengaruh motivasi kerja terhadap kinerja pada PT. Putra Taro Paloma.

- Jika sig $\mathrm{t}>\mathrm{a}$, maka H1o diterima dan H1a ditolak, artinya tidak terdapat pengaruh motivasi kerja terhadap kinerja pada PT. Putra Taro Paloma.

\section{Uji hipotesis kedua}

Hipotesis kedua yang diajukan dalam penelitian ini adalah terdapat pengaruh lingkungan kerja terhadap kinerja pada PT. Putra Taro Paloma. Hipotesis statistik yang diajukan adalah sebagai berikut:

- H2o : b2 = 0 : tidak ada pengaruh

- H2a : b2 $\neq 0$ : ada pengaruh 
Pengujian hipotesis dilakukan dengan uji-t yaitu membandingkan nilai probabilitas (sig t) terhadap taraf uji penelitian ( $\mathrm{a}=0.05)$. Kriteria yang digunakan untuk menguji hipotesis penelitian adalah sebagai berikut:

- Jika sig $\mathrm{t}<\mathrm{a}$, maka H2o ditolak dan $\mathrm{H} 2 \mathrm{a}$ diterima, artinya terdapat pengaruh lingkungan kerja terhadap kinerja pada PT. Putra Taro Paloma.

- Jika sig t > a, maka H2o diterima dan H2a ditolak, artinya tidak terdapat pengaruh lingkungan kerja terhadap kinerja pada PT. Putra Taro Paloma.

\section{HASIL DAN PEMBAHASAN \\ Karakteristik Responden}

Karakteristik responden penelitian berdasarkan usia, jenis kelamin, dan lama bekerja. Berikut dipaparkan hasil dari masing-masing karakteristik responden. Sebagaian besar responden berusia antara $31-40$ tahun yaitu sebanyak 39\%, usia 41 - 50 tahun sebesar 33\%, usia $21-30$ tahun sebesar $25 \%$, dan yang paling sedikit yaitu usia diatas 50 tahun hanya 3\%. Sebagian besar responden berjenis kelamin lakilaki yaitu sebanyak 57\%, sedangkan perempuan sebesar $43 \%$. Sebagian besar responden memiliki masa kerja $3-6$ tahun yaitu sebesar 65\%, $1-3$ tahun sebesear $10 \%$, dan lebih dari 6 tahun sebesar $25 \%$.

\section{Deskripsi Variabel Penelitian}

\section{Deskripsi Variabel Motivasi Kerja}

Di dalam penelitian ini digunakan penilaian terhadap 61 responden dengan menjawab kuesioner 37 pernyataan. Dari hasil jawaban/tanggapan responden dapat diketahui bahwa nilai rata-rata jawaban responden terhadap motivasi kerja (X1) responden yang menjawab sangat tidak setuju $0 \%$, responden yang menjawab tidak setuju $0 \%$, responden yang menjawab kurang setuju 28 orang atau $45.9 \%$, responden yang menjawab setuju 33 orang atau $54.1 \%$, dan responden yang menjawab sangat setuju $0 \%$.

\section{Deskripsi Variabel Lingkungan Kerja}

Di dalam penelitian ini digunakan penilaian terhadap 61 responden dengan menjawab kuesioner 37 pernyataan. Dari hasil jawaban/tanggapan responden dapat diketahui bahwa nilai rata-rata jawaban responden terhadap lingkungan kerja (X2) responden yang menjawab sangat tidak setuju $0 \%$, responden yang menjawab tidak setuju $0 \%$, responden yang menjawab kurang setuju 22 orang atau $36.1 \%$, responden yang menjawab setuju 36 orang atau $59 \%$, dan responden yang menjawab sangat setuju 3 orang atau $4.9 \%$. Dengan demikian secara umum dapat dikatakan bahwa lingkungan kerja (X2) di PT. Putra Taro Paloma Gunung Putri memiliki rata-rata (mean) sebesar 3.69 yang terletak pada interval setuju.

\section{Deskripsi Variabel Kinerja}

Di dalam penelitian ini digunakan penilaian terhadap 61 responden dengan menjawab kuesioner 37 pernyataan. Dari hasil jawaban/tanggapan responden dapat diketahui bahwa nitai rata-rata jawaban responden terhadap motivasi kerja (X1) responden yang menjawab sangat tidak setuju $0 \%$, responden yang menjawab tidak setuju $0 \%$, responden yang menjawab kurang setuju 17 orang atau $27.9 \%$, responden yang menjawab setuju 44 orang atau $72.1 \%$, dan responden yang menjawab sangat setuju $0 \%$. Dengan demikian secara umum dapat dikatakan bahwa kinerja (Y) di PT. Putra Taro Paloma Gunung Putri memiliki rata-rata (mean) sebesar 3.72 yang terletak pada interval setuju.

\section{Instrumentasi Variabel Uji Validitas Variabel (X1) Motivasi Kerja}

Data variabel (X1) motivasi kerja diperoleh dari 11 pernyataan yaitu X1.1 sampai dengan X1.11. Uji reliabilitas variabel (X1) motivasi kerja dilakukan terhadap 11 item pernyataan yang telah valid. Karena hasil uji mendapatkan nilai Cronbach's Alpha lebih besar dari nilai kritis $(0.737>0.6)$ maka variabel (X1) motivasi kerja yang diukur 
menggunakan 11 item pernyataan telah reliabel.

\section{Uji Validitas Variabel \\ Lingkungan Kerja}

(X2)

Data variabel (X2) lingkungan kerja diperoleh dari 16 pernyataan yaitu X2.1 sampai dengan X2.16. Dengan jumlah responden sebanyak 61 orang dan item pernyataan 11 didapat $r$ tabel significancy $0.05=0.252$. Uji validitas variabel (X2) lingkungan kerja dilakukan terhadap 16 item pernyataan. Karena hasil uji mendapatkan nilai $r$ hitung $>r$ tabel (Corrected Item-Total Correlation $>$ 0.3) untuk seluruh item, maka 16 item indikator pengukur variabel

lingkungan kerja seluruhnya valid.

Uji reliabilitas variabel (X2) lingkungan kerja dilakukan terhadap 16 item pernyataan yang telah valid. Karena hasil uji mendapatkan nilai Cronbach's Alpha lebih besar dari nilai kritis (0.754 > 0.6) maka variabel (X2) lingkungan kerja yang diukur menggunakan 16 item pernyataan telah reliabel.

\section{Uji Validitas Variabel (Y) Kinerja}

Data variabel $(\mathrm{Y})$ kinerja diperoleh dari 10 pernyataan yaitu Y1 sampai dengan Y10. Dengan jumlah responden sebanyak 61 dan item pernyataan 10 didapat $r$ tabel significancy $0.05=0.252$. Uji validitas variabel (Y) kinerja dilakukan terhadap 10 item pernyataan. Karena hasil uji mendapatkan nilai $r$ hitung $>\mathrm{r}$ tabel (Corrected Item-Total Correlation > 0.3) untuk seluruh item, maka 10 item indikator pengukur variabel $(\mathrm{Y})$ lingkungan kerja seluruhnya valid.

Uji reliabilitas variabel (Y) Kinerja dilakukan terhadap 10 item pernyataan yang telah valid. Karena hasil uji mendapatkan nilai Cronbach's Alpha lebih besar dari nilai kritis $(0.727>0.6)$ maka variabel $(\mathrm{Y})$ kinerja yang diukur menggunakan 10 item pernyataan telah reliabel.

\section{Uji Normalitas}

Pengujian normalitas secara grafik menghasilkan grafik Normal P-P Plot yang memperlihatkan titik-titik nilai residual pada grafik Normal P-P Plot menyebar di sekitar dan mengikuti arah garis diagonal. Hal ini menunjukkan bahwa data variabel yang digunakan untuk analisis regresi ganda berasal dari data yang berdistribusi normal.

\section{Uji Multikolinearitas}

Dari hasil multikolinearitas, diperoleh pengujian masing variabel independen memiliki nilai tolerance $=0.957$ dan VIF 1.045 . Karena nilai tolerance lebih besar daripada persyaratan minimal $(0.957>$ 0.2) dan nilai VIF lebih rendah dari persyaratan maksimal $(1.045<10)$ maka dapat disimpulkan bahwa analisis regresi linier ganda tidak memiliki masalah multikolinieritas (model yang dikembangkan sudah tepat).

\section{Uji Autokorelasi}

Nilai Durbin-Watson hasil perhitungan sebesar DW $=1.550$. Berdasar kategori yang telah ada, nilai DW termasuk dalam range $1.65<\mathrm{DW}$ $(1.550)<2.35$ yang berarti tidak terjadi autokorelasi. Oleh karena itu analisis regresi linier ganda dapat dilanjutkan.

\section{Uji Heteroskedastisitas}

Grafik scatter plot memperlihatkan bahwa titik-titik hasil perhitungan menyebar secara acak di atas dan di bawah titik origin serta tidak membentuk pola tertentu. Hal ini dapat dikatakan bahwa hasil analisis regresi ganda benar-benar linier karena tidak memiliki masalah heteroskedastisitas sehingga analisis regresi linier ganda dapat dilanjutkan.

Karena persyaratan analisis (asumsi klasik) telah terpenuhi, yaitu memenuhi normalitas, tidak terjadi autokorelasi, tidak terjadi multikolinearitas, tidak terjadi heteroskedastisitas maka analisis regresi linier ganda dapat dilanjutkan. Data yang digunakan adalah data yang telah diuji tanpa melakukan perubahan karena persyaratan asumsi klasik telah terpenuhi semua.

\section{Uji Kelayakan Model}

Analisis data penelitian dilakukan dengan analisis regresi linier ganda. 
Hasil analisis regresi linier ganda yang pertama adalah tabel model summary sebagai berikut:

Tabel 2

Pengaruh Motivasi Kerja dan Lingkungan Kerja Terhadap Kinerja Model Summary

\begin{tabular}{|l|r|r|r|r|}
\hline Model & \multicolumn{1}{|c|}{$\mathrm{R}$} & R Square & $\begin{array}{c}\text { Adjusted R } \\
\text { Square }\end{array}$ & $\begin{array}{c}\text { Std. Error of } \\
\text { the Estimate }\end{array}$ \\
\hline 1 & $.676 \mathrm{a}$ & .457 & .438 & 2.408 \\
\hline
\end{tabular}

a. Predictors: (Constant), Lingkungan Kerja, Motivasi Kerja

Dari tabel tersebut di atas diperoleh nilai koefisien determinasi ganda (Adjusted R Square) sebesar 0.457. Nilai $\mathrm{R} 2=0.457$ menunjukkan bahwa $\mathrm{X} 1$ (motivasi kerja) dan X2 (lingkungan kerja) dalam model secara bersamasama mampu menjelaskan $45,7 \%$ variasi $\mathrm{Y}$ sedangkan $54.3 \%$ variasi $\mathrm{Y}$ lainnya dijelaskan oleh variabel lain yang tidak diteliti. Hasil analisis berikutnya berupa tabel anova yang digunakan untuk menguji hipotesis yaitu pengaruh motivasi kerja dan lingkungan kerja terhadap kinerja.

Tabel 3

Anova Pengaruh Motivasi Kerja dan Lingkungan Kerja Terhadap Kinerja ANOVA $^{a}$

\begin{tabular}{|ll|r|r|r|l|l|}
\hline \multicolumn{2}{|l|}{ Model } & \multicolumn{1}{|c|}{$\begin{array}{c}\text { Sum of } \\
\text { Squares }\end{array}$} & \multicolumn{1}{c|}{ df } & \multicolumn{1}{c|}{$\begin{array}{c}\text { Mean } \\
\text { Square }\end{array}$} & F & Sig. \\
\hline $1 \quad$ & Regression & 61.121 & 2 & 30.561 & 6.023 & $.000^{\circ}$ \\
& Residual & 294.289 & 58 & 5.074 & & \\
& Total & 355.410 & 60 & & & \\
\hline
\end{tabular}

a. Dependent Variable: Kinerja

b. Predictors: (Constant), Lingkungan Kerja, Motivasi Kerja

Berdasarkan hasil analisis pada tabel di atas yakni uji Anova diperoleh $\mathrm{F}$ hitung sebesar 6.023 untuk $N=61$ sebesar 3,16 jadi $\mathrm{F}$ hitung $>\mathrm{F}$ tabel $(\mathrm{a}<$ 0,05 ) atau $6.023>3,16$ dengan tingkat siginifikan 0,000 karena 0,000 $<0,05$, maka dapat dikatakan bahwa motivasi kerja (X1) dan lingkungan kerja (X2) secara bersama-sama berpengaruh positif terhadap kinerja (Y) di PT. Putra Taro Paloma.

Analisis regresi linier ganda juga menghasilkan tabel koefisien yang menunjukkan pengaruh parsial motivasi kerja dan lingkungan kerja terhadap kinerja yaitu sebagai berikut:
Tabel 4

Koefisien Pengaruh Motivasi Kerja dan Lingkungan Kerja Terhadap Kinerja Coefficients $^{\mathrm{a}}$

\begin{tabular}{|c|c|c|c|c|c|c|c|}
\hline \multirow[b]{2}{*}{ Model } & \multicolumn{2}{|c|}{$\begin{array}{c}\text { Unstandardized } \\
\text { Coefficients }\end{array}$} & \multirow{2}{*}{\begin{tabular}{|c|}
$\begin{array}{c}\text { Standardized } \\
\text { Coefficients }\end{array}$ \\
Beta \\
\end{tabular}} & \multirow[b]{2}{*}{$t$} & \multirow[b]{2}{*}{ Sig, } & \multicolumn{2}{|c|}{$\begin{array}{l}\text { Collinearity } \\
\text { Statistics }\end{array}$} \\
\hline & D & $\begin{array}{l}\text { Std. } \\
\text { Crror }\end{array}$ & & & & Tolerance & VIP \\
\hline 1 (Constant) & 28.837 & 2.662 & & 10,831 & .000 & & \\
\hline $\begin{array}{l}\text { Motivasi } \\
\text { Kerja }\end{array}$ & .047 & .055 & .105 & .860 & .000 & .957 & 1.045 \\
\hline $\begin{array}{l}\text { Lingkungan } \\
\text { Kerja }\end{array}$ & .108 & .035 & .380 & 3.112 & .003 & .957 & 1.045 \\
\hline
\end{tabular}

a. Dependent Variable: Kinerja

Dari tabel di atas dapat disusun model persamaan regresi linier ganda berdasar kolom B. Model persamaan regresi linier ganda hasil penelitian adalah sebagai berikut:

$$
\hat{\mathrm{Y}}=28.837+0.047 \mathrm{X} 1+0.108 \mathrm{X} 2
$$

Model persamaan regresi linier ganda hasil analisis tersebut dapat diartikan sebagai berikut:

- Nilai konstanta sebesar a $=28.837$, artinya bahwa jika X1 dan X2 dianggap konstan maka $\mathrm{Y}$ akan bernilai positif.

- Nilai koefisien regresi X1 sebesar b1 = 0.047 menunjukkan bahwa X1 berpengaruh terhadap $\mathrm{Y}$ dengan arah positif.

- Nilai koefisien regresi X2 sebesar b2 = 0.108 menunjukkan bahwa X2 berpengaruh terhadap $\mathrm{Y}$ dengan arah positif.

\section{Pengujian Hipotesis}

Sebelum dilakukan pengujian hipotesis, langkah pertama adalah melakukan pengujian kelayakan model. Kelayakan model dalam menunjukkan pengaruh motivasi kerja dan lingkungan kerja terhadap kinerja ditunjukkan oleh nilai koefisien determinasi ganda $\mathrm{R}$ Square $=0.457$ dengan nilai $\operatorname{sig} \mathrm{F}=$ 0.000 . Hipotesis statistik yang diajukan adalah sebagai berikut:

Ho $: \rho=0:$ tidak layak

Ha $: \rho \neq 0:$ ada layak

$\mathrm{R}$ Square $=0.457$ memiliki nilai probabilitas $\mathrm{F}$ hitung sebesar 0.000 . Karena $\rho$ \# 0 dan probabilitas $F$ hitung lebih kecil daripada taraf uji penelitian (Sig $F<\alpha$ atau $0.000<0.05$ ), maka Ho 
ditolak dan $\mathrm{Ha}$ diterima yang berarti model persamaan regresi ganda pengaruh motivasi kerja (X1) dan lingkungan kerja (X2) terhadap kinerja (Y) adalah layak. Signifikansi hasil pengujian menunjukkan bahwa model penelitian ini diterima dan layak untuk menunjukkan pengaruh motivasi kerja dan lingkungan kerja terhadap kinerja dimana model persamaan hasil penelitian mampu menjelaskan 45,7\% variasi kinerja (Y) karena adanya masukan faktor motivasi kerja (X1) dan lingkungan kerja (X2).

Pengujian hipotesis dilakukan sebanyak dua kali sesuai dengan hipotesis yang diajukan, yaitu sebagai berikut:

\section{Pengujian Hipotesis 1 : Pengaruh Motivasi Kerja terhadap Kinerja}

Hipotesis pertama yang diajukan dalam penelitian ini adalah terdapat pengaruh motivasi kerja terhadap kinerja pada karyawan PT. Putra Taro Paloma. Pengaruhnya ditunjukkan oleh nilai koefisien regresi motivasi kerja (X1) sebesar $\mathrm{b} 1=0.047$ pada model persamaan regresi linier ganda $\hat{\mathrm{Y}}=$ $28.837+0.047 \mathrm{X} 1+0.108 \mathrm{X} 2$. Hipotesis statistik yang diajukan adalah sebagai berikut:

$\mathrm{H} 1 \mathrm{o}: \mathrm{b} 1=0:$ tidak ada pengaruh

$\mathrm{H} 1 \mathrm{a}: \mathrm{b} 1 \neq 0$ : ada pengaruh

Koefisien regresi motivasi kerja (X1) sebesar $\mathrm{b} 1=0.047$ memiliki nilai probabilitas $t$ hitung sebesar 0.000 . Karena b1 \# 0 dan probabilitas t hitung lebih kecil daripada taraf uji penelitian (Sig $\mathrm{t}<\alpha$ atau $0.000<0.05$ ), maka $\mathrm{H} 1 \mathrm{o}$ ditolak dan $\mathrm{H} 1 \mathrm{a}$ diterima yang berarti pengaruh motivasi kerja (X1) terhadap kinerja $(\mathrm{Y})$ adalah signifikan. Signifikansi hasil pengujian menunjukkan bahwa hipotesis pertama penelitian ini diterima yang berarti bahwa terdapat pengaruh parsial motivasi kerja terhadap kinerja dengan arah positif sehingga makin tinggi motivasi kerja maka makin tinggi pula kinerja.

\section{Pengujian Hipotesis 2 : Pengaruh Lingkungan Kerja terhadap Kinerja}

Hipotesis yang kedua dalam penelitian ini adalah terdapat pengaruh lingkungan kerja terhadap kinerja pada karyawan PT. Putra Taro Paloma. Pengaruhnya ditunjukkan oleh nilai koefisien regresi lingkungan kerja (X2) sebesar b2 $=0.108$ pada model persamaan regresi linier ganda $\hat{Y}=$ $28.837+0.047 \mathrm{X} 1+0.108 \mathrm{X} 2$. Hipotesis statistik yang diajukan adalah sebagai berikut:

H2o : b2 $=0$ : tidak ada pengaruh

$\mathrm{H} 2 \mathrm{a}: \mathrm{b} 2 \neq 0$ : ada pengaruh

Koefisien regresi lingkungan kerja (X2) sebesar b2 $=0.108$ memiliki nilai probabilitas $\mathrm{t}$ hitung sebesar 0,003. Karena b2 \# 0 dan probabilitas t hitung lebih kecil daripada taraf uji penelitian (Sig $\mathrm{t}<\alpha$ atau 0,003 $<0,05$ ), maka H2o ditolak dan $\mathrm{H} 2$ a diterima yang berarti pengaruh lingkungan kerja (X2) terhadap kinerja (Y) adalah signifikan. Signifikansi hasil pengujian menunjukkan bahwa hipotesis kedua penelitian ini diterima yang berarti bahwa terdapat pengaruh parsial lingkungan kerja terhadap kinerja dengan arah positif sehingga makin tinggi lingkungan kerja maka makin tinggi pula kinerja.

\section{Pembahasan}

\section{Pengaruh Motivasi Kerja terhadap Kinerja}

Motivasi kerja memiliki pengaruh terhadap kinerja dengan arah positif artinya semakin tinggi motivasi kerja yang diberikan maka semakin tinggi pula kinerja. Pengaruh motivasi kerja terhadap kinerja ditunjukan oleh nilai koefisisen regresi motivasi kerja sebesar $\mathrm{b} 1=0.047$ pada model persamaan regresi linear ganda $\hat{\mathrm{Y}}=28.837+$ $0.047 \mathrm{X} 1+0.108 \mathrm{X} 2$.

Berdasarkan uraian di atas, maka dapat disimpulkan bahwa motivasi merupakan dorongan yang dapat membangkitkan kemauan kerja karyawan untuk memulai melaksanakan pekerjaan sesuai tugas dan tanggung jawabnya. Maka diperoleh hasil bahwa terdapat hubungan antara motivasi terhadap kinerja karyawan. Sehingga karyawan yang memiliki motivasi tinggi dan giat dalam bekerja, maka kinerja akan semakin tinggi. 


\section{Pengaruh Lingkungan Kerja terhadap Kinerja}

Lingkungan kerja memiliki pengaruh terhadap kinerja dengan arah positif artinya semakin baik kondisi lingkungan kerja maka semakin tinggi/baik pula kinerja yang dihasilkan. Pengaruh lingkungan kerja terhadap kinerja ditunjukan oleh nilai koefisisen regresi lingkungan kerja sebesar b2 = 0.108 pada model persamaan regresi linear ganda $\hat{\mathrm{Y}}=28.837+0.047 \mathrm{X} 1+$ $0.108 \times 2$.

Dari uraian di atas dapat disimpulkan bahwa suasana lingkungan kerja adalah kondisi atau keadaan dalam lingkungan kerja, baik dalam arti fisik maupun psikis yang mempengaruhi suasana hati orang yang bekerja, yang mencakup dalam beberapa indikator yaitu fasilitas kerja, tata ruang, kenyamanan, hubungan dengan teman sejawat, dan kebebasan berkreasi. Semakin baik lingkungan kerja maka semakin baik/tinggi pula kinerja yang dihasilkan.

\section{KESIMPULAN}

\section{Simpulan}

- Motivasi kerja memiliki pengaruh terhadap kinerja pada PT. Putra Taro Paloma dengan arah positif sebesar $\mathrm{b} 1=0.047$, artinya makin tinggi motivasi kerja maka makin tinggi pula kinerja di PT. Putra Taro Paloma.

- Lingkungan kerja memiliki pengaruh terhadap kinerja pada PT. Putra Taro Paloma dengan arah positif sebesar b2 $=0.108$, artinya semakin baik lingkungan kerja maka semakin baik pula kinerja di PT. Putra Taro Paloma.

\section{Saran}

Berdasarkan dari hasil penelitian yang dilakukan hendaknya PT. Putra Taro Paloma Gunung Putri memperhatikan motivasi dan lingkungan kerja karyawan sehingga mengakibatkan terciptanya kinerja karyawan yang lebih baik.

- Dalam menentukan kebijakan terkait motivasi dan lingkungan kerja hendaknya pemimpin PT. Putra Taro Paloma Gunung Putri mempertimbangkan hasil dari penelitian yang telah dilakukan sehingga bisa diketahui atau sesuai bentuk motivasi dan lingkungan kerja yang diharapkan oleh karyawan untuk meningkatkan kinerja perusahaan.

\section{DAFTAR PUSTAKA}

Basuki, dan Indah Susilowati. 2005. Dampak Kepemimpinan, dan Lingkungan Kerja, terhadap Semangat Kerja. Jurnal JRBI, Vol. 1 No. 1: 31-47.

Chukwuma, E. $\mathrm{M}$ dan Obiefuna. O. 2014. Effect of Motivation on Employee Productivity : A Study of Manufacturing Companies in Nnewi. Journal of Managerial Studies and Research, Vol. 2 No. 7.

Fahmi, Irham. 2014. Analisa Kinerja Keuangan. Bandung: Alfabeta.

Gujarati, D. N. 2012. Dasar-dasar Ekonometrika. Terjemahan Mangunsong, R. C. Jakarta: Salemba Empat, Buku 2, Edisi 5.

Mangkunegara, A. A. Anwar Prabu. 2013. Manajemen Sumber Daya Manusia Perusahaan. Bandung: Remaja Rosdakarya.

Mangkuprawira, S dan A. V. Hubeis. 2007. Manajemen Mutu Sumber Daya Manusia. Bogor: Penerbit Ghalia Indonesia.

Miftahun, N dan Sugiyanto. 2010. Pengaruh Dukungan Sosial dan Kepemimpinan Transformasional Terhadap Komitmen Organisasi dengan Mediator Motivasi Kerja. Jurnal Psikologi, Vol. 37 No. 1: 94109. Yogyakarta: Universitas Gadjah Mada.

Mulyanto, Heru dan Anna Wulandari. 2012. Penelitian: Metode \& Analisis. Semarang: CV Agung.

Munandar, A. S. 2001. Psikologi Industri dan Organisasi. Jakarta: Universitas Indonesia (UI-Press).

Pamela, A. O dan Oloko. 2015. Effect of Motivation on Employee Performance of Commercial Banks in Kenya: A Case Study of Kenya 
Commercial Bank in Migori County. Journal of Human Resource Studies. Vol. 5 No. 2.

Robbins, Stephen. P dan Mary Coulter. 2012. Management. Eleventh Edition. Jakarta: England.

Santoso, Singgih. 2012. Statistik Parametik. Jakarta: PT. Gramedia Pustaka Umum.

Sugiyono. 2014. Metode Penelitian Pendidikan Pendekatan Kuantitatif, Kualitatif dan R\&D. Bandung: Alfabeta.

Simanjuntak. 2005. Manajemen dan Evaluasi Kinerja. Jakarta: Fakultas Ekonomi Universitas Indonesia.
Umar, Husein. 2005. Metode Penelitian Untuk Skripsi dan Tesis Bisnis. Jakarta: PT. Raja Grafindo Persada.

Wibowo, 2010. Manajemen Kinerja, Edisi Ketiga. Jakarta: Rajawali Pers.

Widodo, Suparno Eko. 2015. Manajemen Pengembangan Sumber Daya Manusia. Yogyakarta: Pustaka Pelajar. 